\title{
The Influence of Thyroxine on the Differentiation of Adipose Tissue and Skin during Fetal Development
}

\author{
GARY J. HAUSMAN \\ Animal Physiology Research Unit, United States Department of Agriculture, Agricultural Research Service, \\ Athens, Georgia 30613
}

\begin{abstract}
Preobese fetuses have elevated thyroid hormone levels and depressed growth hormone levels relative to lean fetuses. Therefore, we are studying various experimental fetal pig models to explore the relationship between endocrine status and onset of obesity. In the present study, intact and hypophysectomized (d 70) fetuses were implanted with thyroxine $\left(\mathrm{T}_{4}\right)$ pellets on $\mathrm{d} 70$ of gestation, and blood, adipose tissue, and skin samples were obtained upon removal of d 90 of gestation. Body weights were similar for all groups and $T_{4}$ treatment reversed myxedema in hypophysectomized fetuses. Serum $T_{4}$ levels were elevated $(p<0.05)$ and skin and hair development were enhanced $(p<0.05)$ to a similar degree by $T_{4}$ treatment in intact and hypophysectomized fetuses. However, $T_{4}$ did not influence adipose tissue development in intact fetuses, but markedly enhanced development in hypophysectomized fetuses. For instance, fat cell size and lipogenic enzyme activities in hypophysectomized fetuses were increased ( $p$ $<0.05$ ) by 5-mg and 15-mg $\mathrm{T}_{4}$ treatments, with a marked increase $(p<0.05)$ in apparent fat cell number with the 15-mg $T_{4}$ treatment. In contrast, there was no effect of $T_{4}$ $(15 \mathrm{mg})$ on these parameters in intact fetuses. Therefore, fetal obesity may be directly associated with elevated thyroid hormone levels and suppressed growth hormone levels, but not with elevated $\mathrm{T}_{4}$ levels alone. (Pediatr Res 32: 204211, 1992)
\end{abstract}

\section{Abbreviations}

hypox, hyphophysectomy/hypophysectomized

GH, growth hormone

$T_{4}$, thyroxine

LPL, lipoprotein lipase

G6PDH, glucose-6-phosphate dehydrogenase

$\mathrm{CV}$, coefficient of variation

AGV, average gray values

$T_{3}$, triiodothyronine

In a number of studies, we have shown that the development of fetal pig adipose tissue was markedly sensitive to genetically or experimentally induced alterations in the endocrine profile (for review see Refs. 1 and 2). For instance, fat cell size and lipogenic enzyme activity were greater in fetuses of genetically obese dams than in fetuses from lean dams (3). When examined

Received January 30, 1992; accepted April 8, 1992.

Correspondence: Dr. Gary J. Hausman, Animal Physiology Research Unit, USDA, ARS, R.B. Russell Research Center, P.O. Box 5677, Athens, GA 30613.

Mention of a trade name, proprietary product, or specific equipment does not constitute a guarantee or warranty by the U.S. Department of Agriculture and does not imply its approval to the exclusion of other products that may be suitable. near term, fat cell size and lipogenic enzyme activity were also increased by fetal hypox on $\mathrm{d} 70$, but hypox significantly reduced fat cell number (4). Furthermore, fat cell number, size, and lipogenic activity were elevated in fetuses obtained from dams made diabetic with alloxan (5). Consideration of the fetal endocrine profiles in these studies indicated that $\mathrm{GH}$ levels were negatively correlated and thyroid hormone levels positively correlated with fat cell development (for review see Refs. 1 and 2). These correlations are strongly supported by results of preadipocyte studies in primary cultures (for review see Refs. 1 and 2). For instance, serum from hypox fetuses produced less preadipocyte proliferation but more differentiation than did serum from control (intact) fetuses when tested on primary cultures of rat preadipocytes (6). Supplementing serum from hypox fetuses with $\mathrm{T}_{4}$ to levels present in control fetuses enhanced its capacity to stimulate rat preadipocyte replication and differentiation in primary cultures (6). Furthermore, normalizing (supplementation) $\mathrm{GH}$ levels in serum from hypox fetuses reduced its capacity to induce differentiation, but had no effect on the capacity to stimulate proliferation in vitro (6). Similar roles for $\mathrm{T}_{4}$ and $\mathrm{GH}$ in preadipocyte development were demonstrated in studies of serum-free cultures of pig cells $(7,8)$.

Therefore, direct (in vitro) and indirect evidence suggests a definitive role for $\mathrm{T}_{4}$ and $\mathrm{GH}$ in fetal adipocyte development. However, the singular influence of $\mathrm{T}_{4}$ and/or $\mathrm{GH}$ on fetal adipocyte development in vivo has not been examined. Therefore, one objective of the present study was to examine adipose tissue development in hypox (ablated d 70) fetuses after normalization of $T_{4}$ levels by implanting slow release $(21 \mathrm{~d}) \mathrm{T}_{4}$ pellets. Because 70-d pig fetuses have very low levels of thyroid hormones $(9,10)$, we also implanted $\mathrm{T}_{4}$ pellets in intact (control) $70-\mathrm{d}$ fetuses. Therefore, another objective of this study was to compare the influence of $\mathrm{T}_{4}$ on adipose tissue development in intact and hypox fetuses.

\section{MATERIALS AND METHODS}

Litters of nine crossbred gilts were studied. After an overnight fast, gilts at $70 \mathrm{~d}$ of gestation $(3 / 5$ of term) were premedicated with sodium thiopental and then prepared for surgery as described elsewhere (11). Gilts were maintained with halothane (fluothane) in oxygen and vital signs were recorded continuously during surgery and the postoperative period. An incision was made midventral, cranial to the pubic symphysis, and the uterine horns exteriorized from the abdominal cavity. Subsequent surgical procedures are generally described elsewhere (12). In short, fetal hypox was performed by electrocoagulation with a fine, insulated (except for the tip) cautery needle (12). The fetus was palpated to the antimesometrial surface of the uterus, where there are few blood vessels and the amnion is fused to the chorion. A hole was made into the frontal bone of the fetus with an 18- 
gauge needle and the cautery needle was placed in the hole and guided blindly to the floor of the cranium and into the pituitary fossa. The pituitary was then electrocoagulated for several seconds.

At this point, some of the hypox fetuses received $T_{4}$ pellets (21-d release; Innovative Research of America, Toledo, $\mathrm{OH}$ ) by first palpating the fetus to the antimesometrial surface and making a small incision in the uterine wall. The uterine incision was raised to prevent loss of amniotic fluid. A small pocket was made in the lateral musculature of an exposed hind leg with a small, blunt hemostat for placement of a $\mathrm{T}_{4}$ pellet. It was not necessary to suture the fetal leg incision. A broad spectrum antibiotic was liberally applied around the fetus before closing the uterine incision (12). Fetal membranes and the uterine wall were closed together with a continuous 5.0 silk suture preventing placental separation and conjoining of fetal and maternal circulations (12). This was overlaid with a line of Lambert sutures. At $90 \mathrm{~d}$ of gestation ( $4 / 5$ of term), midline laparotomies were performed on anesthetized dams and fetal blood samples drawn from the umbilical artery and fetuses were collected, dried, and weighed. Fetuses were examined in detail and individual organs (e.g. heart, liver, lungs, and kidneys) were removed, weighed, and closely examined. The completeness of the hypox was assessed by careful examination of the pituitary fossa for tissue remnants. Confirmation of hypox was also made by measurement of serum cortisol and LH concentrations.

Pellets were implanted exclusively in hypox fetuses in four litters. One to two groups of three fetuses consisting of a control, a hypox fetus, and a $\mathrm{T}_{4}$-treated (15-mg pellet) hypox fetus were obtained from each of these four litters. In five additional litters, control (intact) and hypox fetuses were implanted with either 5mg or $15-\mathrm{mg} \mathrm{T}_{4}$ pellets. In three of these litters, all experimental fetuses survived, resulting in the following group of six fetuses: a control, a hypox fetus, a 5-mg and 15-mg-treated hypox fetus and a 5-mg and 15-mg-treated control. As a result of fetal death, the other two litters contained incomplete groups, with the collective loss of a 15-mg-treated control and a 5-mg- and 15mg-treated hypox fetus. In two litters, untreated hypox fetuses were implanted with placebo pellets (15-mg size).

Histology and histochemistry. As detailed elsewhere (13), 2- to 3-mm wide blocks of dorsal-most subcutaneous tissue (including skin and adipose) from the shoulder were removed immediately and prepared for histologic and histochemic studies. One fourth of the tissue blocks were fixed in Bouin's fixative and routinely processed into paraffin blocks. The remaining blocks were snapfrozen in isopentane, cooled in liquid $\mathrm{N}_{2}$, and stored in an ultracold freezer. Details are given elsewhere for routine staining procedures for cryostat $\left(-20^{\circ} \mathrm{C}\right)$ sections of frozen tissue (14) and for sections of wax-embedded tissues (13).

Immunocytochemistry and enzyme cytochemistry. Air-dried, freshly frozen, 24- and 48- $\mu \mathrm{m}$ cryostat sections were reacted for esterase (EC 3.1.1.1; Ref. 14), LPL, (Ref. 3), and G6PDH, (EC 1.1.1.42) (15) enzymes. Cryostat sections were incubated with a polyclonal antibody against mouse tumor laminin (Chemicon, El Segundo, CA) at a 1:250 dilution followed by goat (FITC) anti-rabbit IgG $(200 \mu \mathrm{g} / \mathrm{mL}$; Sigma Chemical Co., St. Louis, $\mathrm{MO}$ ) in a protocol reported elsewhere (16). After immuno- and/ or cytochemistry, cryostat sections were fixed for $10 \mathrm{~min}$ at room temperature in $4 \%$ paraformaldehyde, rinsed with PBS, and mounted in Elvanol (16a).

Quantitative analysis of stained cryostat sections. Within individual sections, the percentage of the area either reactive for LPL and G6PDH or stained for lipid (oil red O) was quantified by computer-assisted image analysis using a Dage CCD-72 camera (Dage-MT1, Michigan City, IN) and 1M-3000 software (Analytical Imaging Concepts, Irving, CA). Viewed at $35 \times$ magnification, the pixel size of the video screen was $5.3 \times 4.3 \mu \mathrm{m}$. Figure 1 demonstrates the location and size of the area analyzed in the inner layer of adipose tissue. Gray values range between 0 (black) and 256 (white). Lipid-stained sections were analyzed at a thresh-

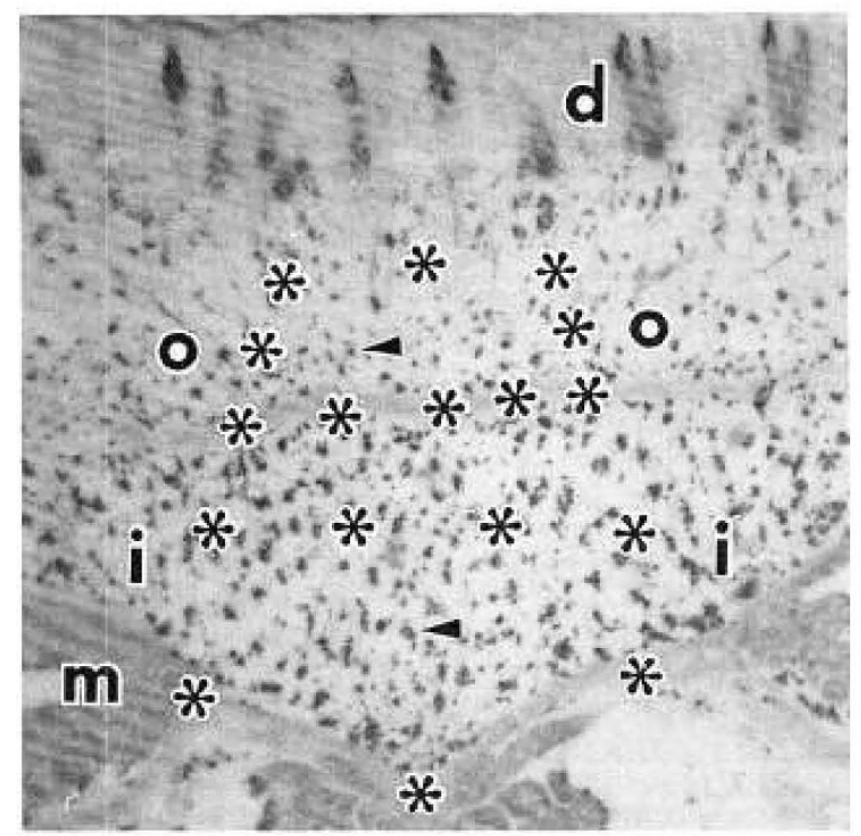

Fig. 1. Morphology of subcutaneous adipose tissue (dorsal most) from a 90-d control (intact) fetus. Fat cell clusters (arrowheads) are obvious in the outer $(0)$ and inner $(i)$ layers of adipose tissue in this lipidstained cryostat $(25 \mu \mathrm{m})$ section. The areas analyzed by computer-assisted image analysis are outlined in the outer and inner layers. Also indicated are dermis $(d)$ and muscle $(m)$. Original magnification, $\times 10$.

old of 125, whereas G6PDH- and LPL-reacted sections were analyzed at a threshold of 55 . Table 1 characterizes the image analysis in regard to the number and total area of thresholded objects (fat cell clusters). A similar number of fat cell clusters were thresholded within a treatment group for LPL- and G6PDH-reacted sections (Table 1). In lipid-stained sections, the number of fat cell clusters (thresholded objects) was similar for control and hypox fetuses, whereas the total cluster area and therefore the average cell cluster area were greater for hypox fetuses (Table 1), which is consistent with morphologic observations (Fig. 2). As planned, the total area (object area plus area not thresholded) analyzed per section was similar across treatment groups within a stain or enzyme reaction group. For instance, the total area analyzed per section for lipid-stained sections was (mean $\pm \mathrm{SEM} ; \mathrm{mm}^{2}$ ) $7.2 \pm 0.17$ (15 mg, hypox), $7.3 \pm 0.24$ (control), and $7.55 \pm 0.26$ (hypox). To evaluate the repeatability of this type of measurement, LPL-reacted sections from five pairs of hypox and control fetuses (five dams) were analyzed on two different days; total area analyzed and thresholded object area and number were not significantly influenced by day of analysis $(p>0.05)$.

The area in the outer layer (adipose tissue) depicted in Figure 1 was analyzed with respect to number of thresholded objects (fat cell cluster number). The number of fat cell clusters and the foci of blood vessels were counted in the outer layer of micrographs of antilaminin-stained sections from hypox, hypox +15 $\mathrm{mg} \mathrm{T}_{4}$, and control fetuses $(n=3)$.

Fat cell sizes. Fat cell diameters were determined on sections of paraffin-embedded tissues according to Sjostrom et al. (17). Twenty-five diameters were measured for each fetus in sections stained with the periodic acid-Schiff reagents (18) to demonstrate basal laminae. Only cells with a prominent basal lamina were measured.

Hormone assays. Blood was kept on ice for $4 \mathrm{~h}$ before centrifugation and harvesting serum.

Serum cortisol was measured using a coated tube RIA kit (Ventrex Laboratories, Inc., Portland, ME). The kit provides tracer, antibody-coated tubes, standards, and high and low pools. Samples were pipeted into coated tubes, cortisol tracer was added 
Table 1. Image analysis of lipid staining and reactivity for

G6PDH and LPL enzymes in sections of adipose tissue from control, hypox, and $T_{4}(15 \mathrm{mg})$-treated hypox fetuses*

\begin{tabular}{lccc}
\hline & $\begin{array}{c}\text { Number of } \\
\text { thresholded } \\
\text { objects }\end{array}$ & $\begin{array}{c}\text { Total area of } \\
\text { thresholded } \\
\text { objects } \\
\left(\mu \mathrm{m}^{2}\right)\end{array}$ & $\begin{array}{c}\text { Average gray } \\
\text { values } \ddagger\end{array}$ \\
\hline $\begin{array}{l}\text { Lipid staining } \\
\text { Control }\end{array}$ & $135 \pm 9.2 \S$ & $762 \pm 52 \S$ & $\mathrm{ND}$ \\
Hypox & $107 \pm 14 \S$ & $1286 \pm 132 \|$ & $\mathrm{ND}$ \\
Hypox $+\mathrm{T}_{4}$ & $\mathrm{ND}$ & $2733 \pm 470 \AA$ & $\mathrm{ND}$ \\
G6PDH & & & \\
Control & $10.2 \pm 10 \S$ & $77 \pm 70 \S$ & $50.5 \pm 1.2 \S$ \\
Hypox & $53 \pm 11 \|$ & $545 \pm 186 \|$ & $46.6 \pm 0.85 \|$ \\
Hypox $+\mathrm{T}_{4}$ & $37 \pm 10 \|$ & $3680 \pm 518 \pi$ & $46 \pm 1.2 \|$ \\
LPL & & & \\
Control & $11 \pm 9.4 \S$ & $60 \pm 40 \S$ & $46.4 \pm 1.6 \S$ \\
Hypox & $67 \pm 10 \|$ & $795 \pm 152 \|$ & $41 \pm 1.6 \|$ \\
Hypox $+\mathrm{T}_{4}$ & $35 \pm 9 \|$ & $2707 \pm 440 \pi$ & $35.6 \pm 1.6 \uparrow$ \\
\hline
\end{tabular}

${ }^{*}$ Lipid-stained sections were analyzed at a threshold of 125 , whereas G6PDH- and LPL-reacted sections were analyzed at a threshold of 55. Thresholded objects represent fat cell clusters as viewed at a magnification of $35 \times$. Gray values range between 0 (black) and 256 (white). When sections were incubated without substrates (LPL and G6PDH), there were no thresholded objects and therefore no object area regardless of fetal treatment. ND $=$ not determined.

$\dagger$ Least squares mean \pm SEM of five to six fetuses (per group); duplicate slides (sections) were used per fetus. Within the control and hypox treatment groups, total object area and number were greater $(p<0.05)$ in lipid-stained sections than in G6PDH- and LPL-reacted sections, with no significant differences between G6PDH and LPL sections regarding these parameters. Within the hypox $+\mathrm{T}_{4}$ group, object number and area were similar $(p>0.05)$ regardless of stain or reaction. As planned, the average total area analyzed per section was similar for all stains (or reactions) and treatments.

$\ddagger$ Least squares mean \pm SEM of five to six fetuses (duplicate sections per fetus). These values represent the average gray value of the number of thresholded objects (fat cell clusters) shown above.

$\S \cdot \| \cdot \pi$ Within a column and within a stain or reaction group means with different superscripts are different $(p<0.05)$.

and the assay was incubated for $45 \mathrm{~min}$ at $37^{\circ} \mathrm{C}$. The tubes were decanted and radioactivity was determined. Assay sensitivity was $15 \mathrm{nmol} / \mathrm{L}$. The intraassay $\mathrm{CV}$ was $9.31 \%$ and interassay $\mathrm{CV}$ was $7.01 \%$.

$\mathrm{T}_{4}$ concentrations were measured using a Ventrex coated tube RIA. The kit provides $\mathrm{T}_{4}$ antibody coated tubes, $\mathrm{T}_{4}{ }^{125} \mathrm{I}$ tracer, assay buffer, and standards. Samples were pipeted into coated tubes, tracer was added, and the assay was incubated for $1 \mathrm{~h}$ at $20-25^{\circ} \mathrm{C}$. Tubes were inverted and radioactivity was determined. Sensitivity of the assay was $6.4 \mathrm{nmol} / \mathrm{L}$. The intraassay CV was $3.5 \%$ and interassay $\mathrm{CV}$ was $3.3 \%$.

Serum LH concentrations were determined using a double antibody assay routinely used and validated in this lab (19). Samples and standard curves were incubated in first antibody (rabbit anti-bovine LH, developed by this lab) and 1\% BSA for $24 \mathrm{~h}$ at $4^{\circ} \mathrm{C}$. A second antibody (sheep anti-goat, anti-rabbit) and polyethylene glycol were added to the assay tubes, which were vortexed and centrifuged for $15 \mathrm{~min}$ at $3000 \mathrm{rpm}(2100 \times \mathrm{g})$. The supernatant was poured off and the inverted tubes were allowed to dry for several hours before radioactivity was determined. Assay sensitivity was $0.15 \mathrm{IU} / \mathrm{L}$. Intraassay $\mathrm{CV}$ was $6.0 \%$ and the interassay $\mathrm{CV}$ was $10.2 \%$.

Serum concentrations of insulin were determined with a double antibody RIA kit. Insulin tracer and antiserum, pools, standards, and precipitating reagent are provided in the kit. Unknowns were pipeted into $12 \times 75$ borosilicate tubes. Insulin tracer and antiserum were then added. The assay tubes were vortexed and incubated at room temperature for $90 \mathrm{~min}$. Precipitating reagent

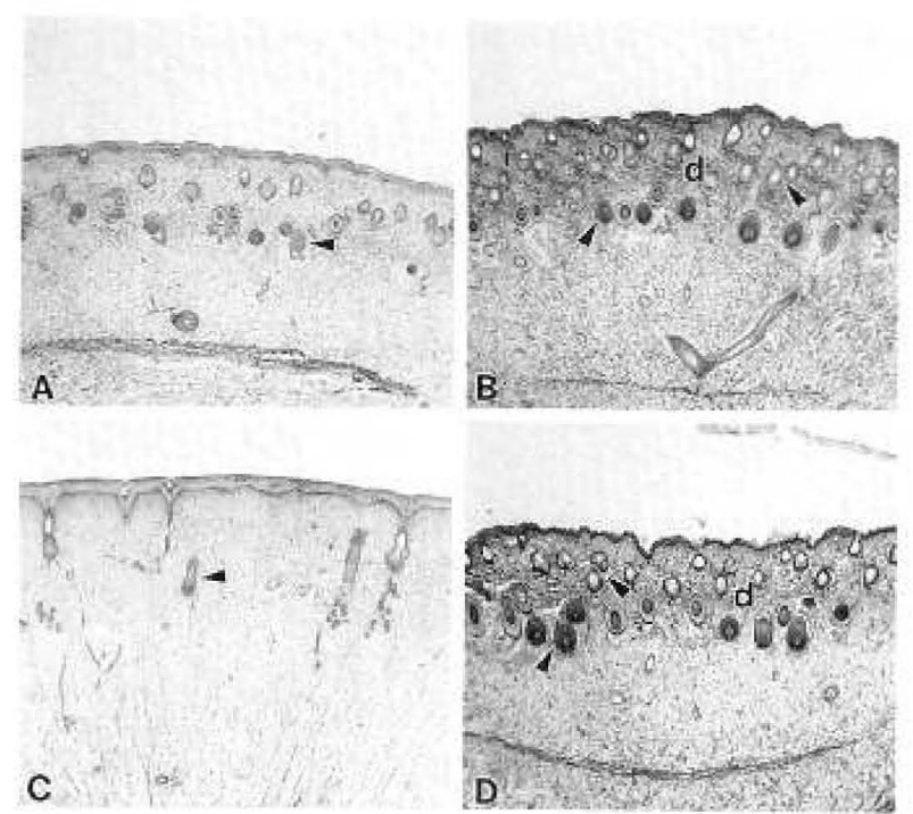

Fig. 2. The morphology of skin from $A$, a 90-d control (intact) fetus; $B$, a control fetus with $15-\mathrm{mg} \mathrm{T}_{4}$ pellet; $C$, a hypox fetus; and $D$, a hypox fetus with a $15-\mathrm{mg} \mathrm{T}_{4}$ pellet. The number of hair follicles and hair shafts (arrowheads) are markedly increased by $\mathrm{T}_{4}$ treatment of hypox and intact fetuses. ( $A$ vs $B, C$ vs $D$ ) and the demarcation of dermis $(d)$ from subcutaneous tissue is more pronounced in sections from $\mathrm{T}_{4}$-treated fetuses ( $B, D$ vs $A, C)$. Sections from paraffin-embedded blocks stained for connective tissue with the picro ponceau reagents (18). Original magnification, $\times 20$.

was added and the samples were incubated for another $20 \mathrm{~min}$ at room temperature. The assay was centrifuged at $1500 \times g$ for $10 \mathrm{~min}$ and the tubes were decanted before radioactivity was determined. Assay sensitivity was $9 \mathrm{pmol} / \mathrm{L}$. The intraassay CV was $4.5 \%$ and the interassay CV was $6.4 \%$.

Statistics. Data were subjected to an analysis of variance procedure of the Statistical Analysis Systems (20) to determine the main effects of fetal condition (hypox versus control), treatment $\left(\mathrm{T}_{4}\right)$, and condition $\times$ treatment interactions. The main effect of dam or litter (all fetuses from one dam) per se could not be determined, because one group of fetuses (i.e. a hypox, control, hypox $+\mathrm{T}_{4}$, etc.) was obtained from seven of the nine dams used. As a result, each fetus represented a separate dam ( $n$ $=6$ fetuses $=6$ dams) for most measurements. Differences between means were determined by the least squares contrasts of the Statistical Analysis Systems procedure.

\section{RESULTS}

In all but six of the hypox fetuses, the ablation was judged to be complete. Mean cortisol concentrations were higher $(p<$ 0.05 ) in control (intact) fetuses than in hypox fetuses regardless of thyroxine treatment (Table 2). Serum LH concentrations for 13 hypox fetuses were less than the assay sensitivity $(0.22 \mathrm{IU} / \mathrm{L})$, which contrasts with the mean $( \pm$ SEM $)$ LH concentration for 17 intact fetuses, i.e. $1.26 \pm 0.24 \mathrm{IU} / \mathrm{L}$. LH and cortisol values for hypox fetuses were similar in the present and another study (21), which supports the use of these parameters to confirm the visual appraisal of hypox. Serum $\mathrm{T}_{4}$ concentrations were elevated $(p<$ 0.05 ) in 5-mg and $15-\mathrm{mg} \mathrm{T}_{4}$-treated hypox fetuses and in $15-\mathrm{mg}$ $\mathrm{T}_{4}$-treated intact fetuses when compared with $\mathrm{T}_{4}$ levels in their respective controls (Table 2). Serum samples from four to five control, hypox, and 15-mg $\mathrm{T}_{4}$-hypox fetuses were assayed for $\mathrm{T}_{3}$, but all values were below $0.47 \mathrm{nmol} / \mathrm{L}$, which was the lowest level detectable by the assay. Serum samples from four control and four 15-mg $\mathrm{T}_{4}$ control fetuses were assayed for $T_{3}$ by Roche 
THYROXINE AND FETAL ADIPOSE TISSUE

Table 2. Body weight, serum hormone levels, and morphologic traits of skin and adipose tissue for control and hypox pig fetuses treated with 5-mg or 15-mg $T_{4}$ pellets*

\begin{tabular}{|c|c|c|c|c|c|c|}
\hline & \multicolumn{6}{|c|}{ Treatment groups } \\
\hline & Control & Control-5 mg & Control-15 mg & Hypox & Нypox-5 mg & Нypox-15 mg \\
\hline Body wt (g) & $580 \pm 46 \ddagger$ & $541 \pm 76 \ddagger$ & $441 \pm 68 \ddagger$ & $594 \pm 46 \ddagger$ & $473 \pm 88 \ddagger$ & $517 \pm 46 \ddagger$ \\
\hline $\mathrm{T}_{4}(\mathrm{nmol} / \mathrm{L})$ & $66 \pm 13 \ddagger$ & $58 \pm 19 \ddagger$ & $188 \pm 22 \S$ & $1.1 \pm 12 \|$ & $58 \pm 22 \ddagger$ & $152 \pm 13 \S$ \\
\hline Cortisol (nmol/L) & $113 \pm 6.5 \ddagger$ & $75 \pm 25 \ddagger$ & $73 \pm 25 \ddagger$ & $19 \pm 14 \S$ & $24 \pm 25 \S$ & $19 \pm 14 \S$ \\
\hline $\begin{array}{l}\text { Subcutaneous tissue } \\
\text { thickness }(\mathrm{mm}) \dagger\end{array}$ & $4.75 \pm 0.38 \ddagger$ & $3.85 \pm 0.66 \ddagger \S$ & $3.11 \pm 0.35 \S$ & $4.66 \pm 0.35 \neq$ & $3.1 \pm 0.54 \S$ & $3.48 \pm 0.33 \S$ \\
\hline $\begin{array}{l}\text { Hair follicles, and hair } \\
\text { shafts } / 10 \mathrm{~cm} \dagger\end{array}$ & $26.6 \pm 3.2 \ddagger$ & $48 \pm 3.8 \S$ & $62.8 \pm 4.23 \|$ & $14.65 \pm 5.9 \ddagger$ & $50 \pm 5.9 \S$ & $55.4 \pm 4.2 \S$ \\
\hline $\begin{array}{l}\text { Fat cell cluster no.-outer } \\
\text { layer } / \mathrm{mm}^{2}\end{array}$ & $13.77 \pm 1.9 \$ \S$ & $16.5 \pm 3.4 \ddagger \S$ & $20.8 \pm 2.8 \ddagger \|$ & $11.32 \pm 2.0 \S$ & $11.3 \pm 2.8 \S$ & $19.55 \pm 1.6 \|$ \\
\hline
\end{tabular}

* Least squares mean \pm SEM for 10 to 11 fetuses each for the hypox-15 $\mathrm{mg}$, control, and hypox groups, and three to five fetuses each for the control-15 mg, control-5 mg, and hypox-5 mg groups. There was a significant main effect $(p<0.01)$ of $\mathrm{T}_{4}$ treatment, but no effect of fetal condition (hypox vs control) on fat cell cluster numbers, hair follicle and hair shaft density, and subcutaneous thickness. Main effects of $\mathrm{T}_{4}$ treatment $(p<$ $0.001)$ and fetal condition were significant for $\mathrm{T}_{4}$ levels, whereas only fetal condition affected $(p<0.01)$ cortisol levels. There were no significant treatment $\times$ condition interactions for these parameters.

† Thickness measurements included the outer and inner layers of adipose tissue, but excluded the dermis and epidermis. The number of hair follicle and hair shaft profiles in skin cross-sections (relative to the long axis of the body) were counted.

$¥ \S \|$ Means within a row with different superscripts are different $(p<0.05)$.

Biovet (Burlington, NC) and values for two control fetuses and one $\mathrm{T}_{4}$-treated fetus were below assay detectability of $0.31 \mathrm{nmol} /$ $\mathrm{L}$. The mean $\pm \mathrm{SEM}$ of $\mathrm{T}_{3}$ values for the remaining fetuses were $0.44 \pm 0.05 \mathrm{nmol} / \mathrm{L}$ for controls and $0.52 \pm 0.11 \mathrm{nmol} / \mathrm{L}$ for $\mathrm{T}_{4}$ $(15 \mathrm{mg})$-treated controls. Therefore, $\mathrm{T}_{4}$ treatment did not significantly elevate $T_{3}$ levels in hypox and intact (control) fetuses. Insulin concentrations were not affected by hypox or $\mathrm{T}_{4}$ treatment and were (mean \pm SEM, $n=6) 18 \pm 0.72,20 \pm 3.2$ and $21 \pm 1.5 \mathrm{pmol} / \mathrm{L}$ for control, hypox, and $15 \mathrm{mg}$ hypox groups, respectively. Hypox fetuses had a typical appearance, i.e. edematous and hairless (4), whereas $T_{4}$ treatment antagonized this edematous condition and was associated with a light hair coat. Intact fetuses treated with $15 \mathrm{mg} \mathrm{T}$ were similar in appearance to $\mathrm{T}_{4}$-treated hypox fetuses.

Body weights and skin development. $\mathrm{T}_{4}$ treatment of intact (controls) and hypox fetuses and hypox per se had no influence on body weight (Table 2). The development of hair follicles and hair shafts was markedly enhanced by $T_{4}$ treatment of intact and hypox fetuses (Fig. 2 and Table 2). A dose ( $\left.T_{4}\right)$-dependent increase in hair follicle and shaft density was evident in intact fetuses (Table 2) and, as expected, untreated hypox fetuses had the lowest density of hair follicles and shafts (Fig. 2 and Table 2 ). The deposition of connective tissue in the dermis was also enhanced by $\mathrm{T}_{4}$ treatment of intact and hypox fetuses, resulting in greater demarcation of dermis from subcutaneous tissue (Fig. 2 ). Thickness of the subcutaneous adipose tissue was significantly reduced by $5-\mathrm{mg}$ and $15-\mathrm{mg} \mathrm{T}_{4}$ treatment of hypox fetuses and by $15-\mathrm{mg} \mathrm{T}_{4}$ treatment of intact fetuses (Table 2). Associated with the reduced tissue thickness was a reduction in the edematous condition and a greater condensation of connective tissue fibers (data not shown).

Morphology and histochemistry of the middle layer of adipose tissue. Treatment of hypox fetuses with $15 \mathrm{mg} \mathrm{T}$ significantly increased the size of fat cell clusters, whereas treatment of intact fetuses with this dose of $\mathrm{T}_{4}$ had no influence on fat cell cluster size (Fig. 3). Accordingly, image analysis of lipid-stained sections showed that the percentage of area occupied by fat cell clusters was not affected by $\mathrm{T}_{4}$ treatment except for a 1 -fold increase induced by the high dose of $\mathrm{T}_{4}$ in hypox fetuses (Fig. 4). Hypox per se was associated with subtle changes in fat cell cluster morphology (Figs. 3 and 4).

$\mathrm{T}_{4}$ treatment of intact fetuses had no influence on the percentage of tissue area (in sections) reactive for LPL and G6PDH enzymes (Fig. 4). These percentages (LPL, G6PDH) were significantly increased by hypox and were increased even further by the combination of hypox and $T_{4}$ treatment (Fig. 4). $T_{4}$ treatment markedly enhanced the percentage of enzyme (LPL, G6PDH)reactive fat cell clusters when compared with hypophysectomy alone (Fig. 4). The extent of esterase reactivity was greatest in sections from $\mathrm{T}_{4}$-treated hypox fetuses and least (none) in sections from intact and $\mathrm{T}_{4}$-treated $(15 \mathrm{mg}$ ) intact fetuses (Fig. 5).

The AGV shown in Table 1 are indicative of the intensity of the enzyme reaction; the lower the $\mathrm{AGV}$, the greater the enzyme reaction. Activity of LPL (staining intensity) was enhanced (lower AGV) by hypox and increased further with the combination of $\mathrm{T}_{4}$ treatment and hypox (Table 1). Values (LPL-AGV) for 5-mg $\mathrm{T}_{4}$-hypox fetuses were (mean $\pm \mathrm{SEM}$ ) $34 \pm 2.3$ and values for 15 - $\mathrm{mg} \mathrm{T}_{4}$ intact fetuses were $46.8 \pm 2.8$. Therefore, $\mathrm{T}_{4}$ treatment of intact fetuses had no influence on LPL activity, whereas 5-mg and $15-\mathrm{mg} \mathrm{T}_{4}$ treatment of hypox fetuses significantly increased LPL activity (Table 1). Activity of G6PDH (AGV) was enhanced by hypox, but $\mathrm{T}_{4}$ treatment of intact (data not shown) and hypox fetuses had no influence on G6PDH activity (Table 1).

Fat cell size and morphology. $\mathrm{T}_{4}$ treatment of intact fetuses had no influence on fat cell size, i.e. fat cell diameters-least squares means \pm SEM for four fetuses: for controls, $14.4 \pm 0.3$; and for controls with $15-\mathrm{mg} \mathrm{T}_{4}$ pellets, $14.1 \pm 0.4$. Treatment of hypox fetuses with $\mathrm{T}_{4}$ resulted in a slight increase $(p<0.05)$ in fat cell size, i.e. cell diameters-least squares mean \pm SEM for six fetuses: for hypox, $21.6 \pm 0.75$; hypox with $5 \mathrm{mg} \mathrm{T}, 24.5 \pm$ 0.93 ; and hypox with $15 \mathrm{mg} \mathrm{T}, 24.5 \pm 0.75$. Fat cell size was significantly increased by hypox (see above and Fig. 6). Fat cells in hypox and $\mathrm{T}_{4}$-treated and untreated intact fetuses typically had many lipid droplets (multilocular), whereas fat cells in 15$\mathrm{mg} \mathrm{T}_{4}$-treated hypox fetuses were predominantly unilocular (one lipid droplet), despite the similarity in cell size for hypox and $T_{4}$ (15 mg)-treated hypox fetuses (Fig. 6). In 5-mg T4-treated hypox fetuses, the number of unilocular cells was less than that for 15 mg-treated hypox fetuses, but much more than that for untreated hypox fetuses (data not shown).

Morphology of the outer layer of adipose tissue. Image analysis of the outer layers in lipid-stained sections showed that fat cell cluster (threshold objects) number was not influenced by hypox or by $\mathrm{T}_{4}$ treatment, except for the high $\mathrm{T}_{4}$ dose in hypox fetuses (Table 2). The number of fat cell clusters and blood vessel foci in the outer layers of sections stained for laminin (antilaminin) were (mean \pm SEM; $n=3) 28.5 \pm 1.3,30 \pm 1.7$, and $28 \pm 1.6 /$ $\mathrm{mm}^{2}$ for hypox, $\mathrm{T}_{4}$-treated $(15 \mathrm{mg}$ ) hypox, and intact fetuses, respectively. These values were not significantly different from each other $(p<0.05)$. 

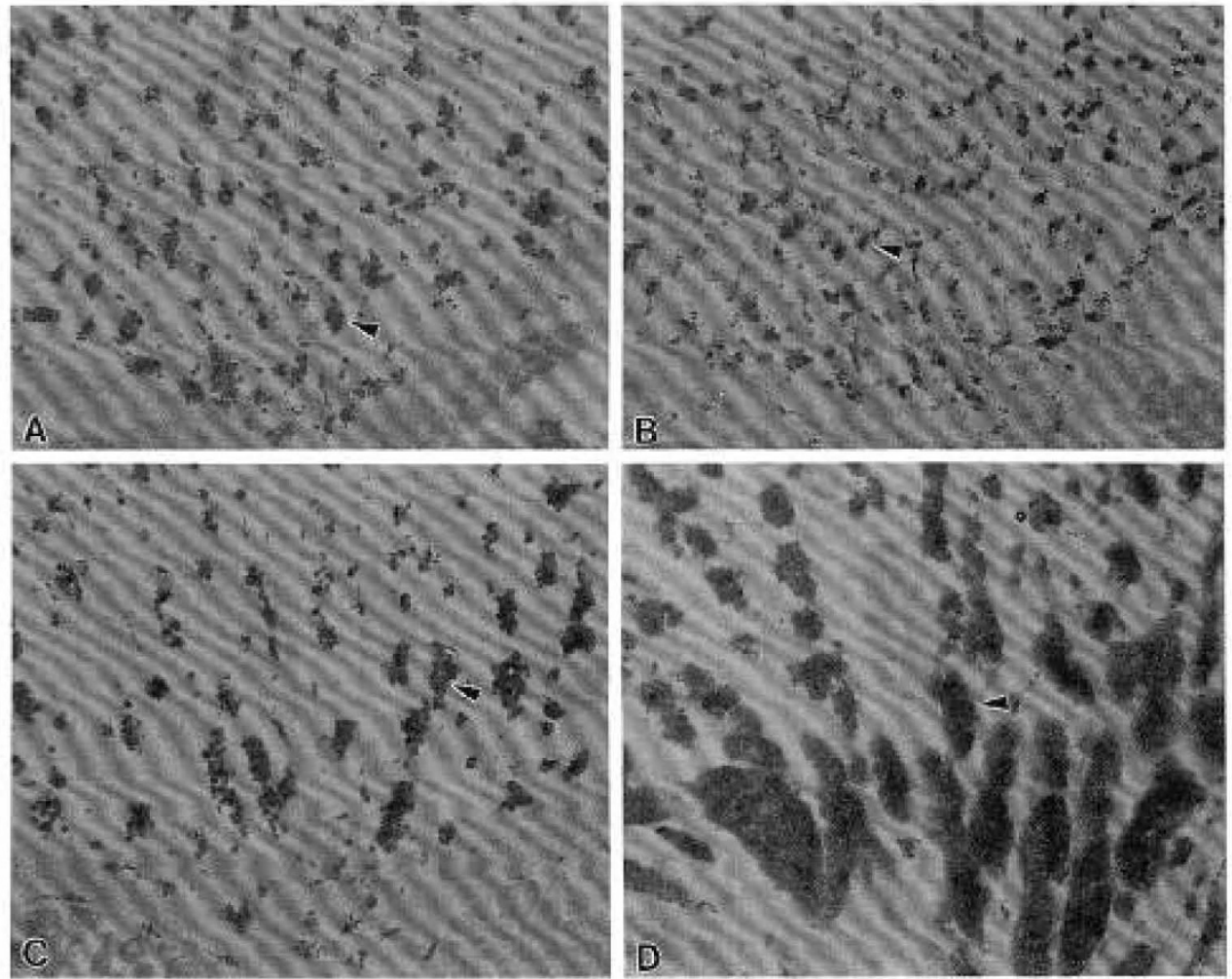

Fig. 3. The morphology of fat cell clusters (arrowheads) in lipid-stained sections (inner layer) from $A$, a control (intact) fetus; $B$, a control fetus with a $15-\mathrm{mg} \mathrm{T}_{4}$ pellet; $C$, a hypox fetus; and $D$, a hypox fetus with a $15-\mathrm{mg} \mathrm{T}_{4}$ pellet. Fat cell cluster morphology was not influenced by $\mathrm{T}_{4}$ treatment of control fetuses $(A v S B)$. However, $T_{4}$ treatment of hypox fetuses markedly increased fat cell cluster size $(C v s D)$. Cryostat sections stained with oil red $O$. Original magnification, $\times 50$.

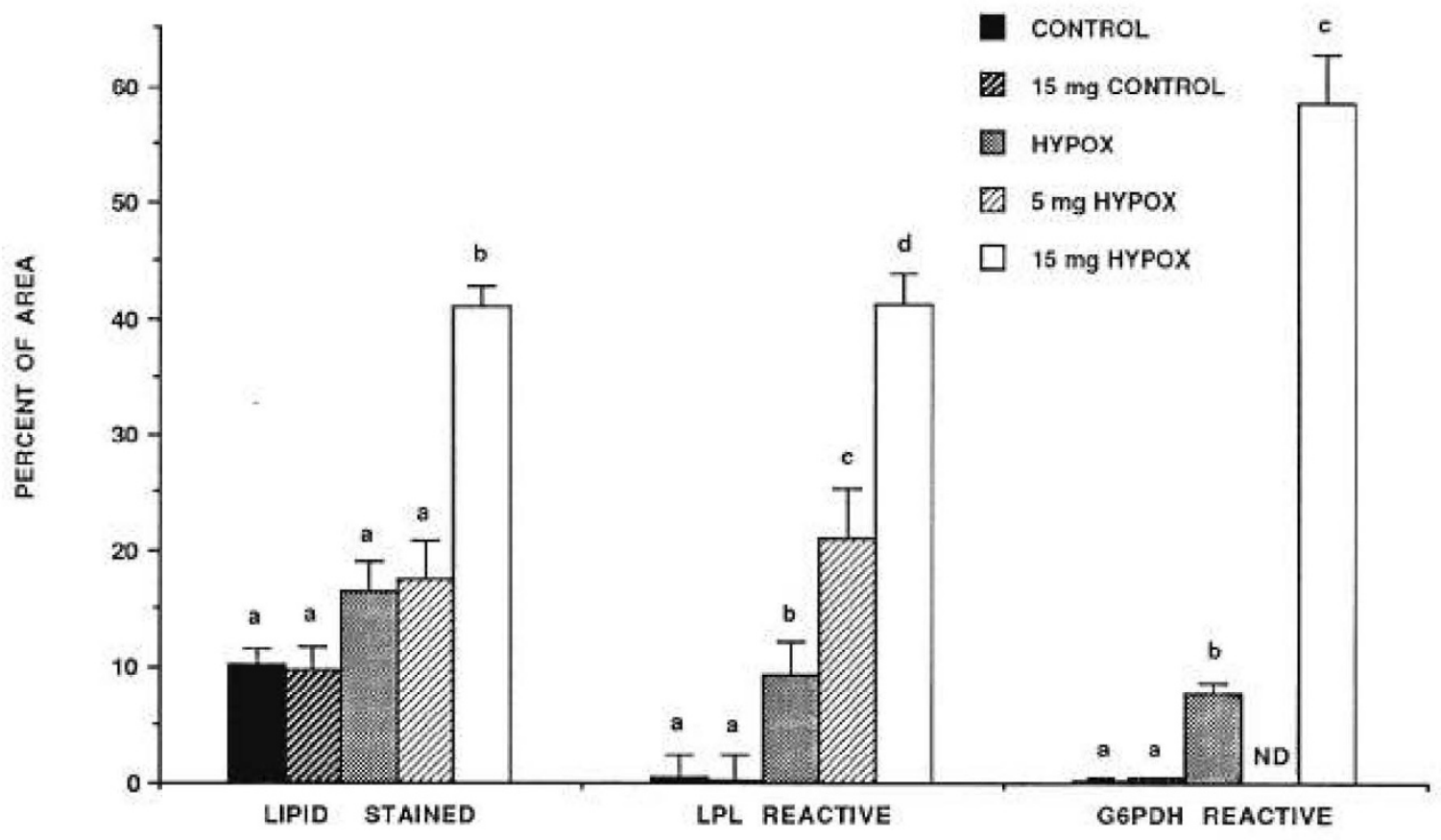

FAT CELL CLUSTERS

Fig. 4. Image analysis of lipid-stained and enzyme-reacted adipose tissue sections from control (intact) fetuses, control with 15 -mg $\mathrm{T}_{4}$ pellets $(15$ $\mathrm{mg}$ control), hypox fetuses, and hypox with 5-mg (5 mg hypox) and 15-mg (15 mg hypox) $\mathrm{T}_{4}$ pellets. An area of the middle layer was analyzed with respect to the percentage of area occupied by either fat cell clusters (lipid-stained sections), G6PDH-reactive clusters or LPL-reactive fat cell clusters. Least squares mean \pm SEM of six fetuses for control, hypox, and $15 \mathrm{mg}$ hypox groups and four fetuses for $15 \mathrm{mg}$ control and $5 \mathrm{mg}$ hypox groups. Within the staining groups, means (bars) with different superscripts are different $(p<0.05)$. There were significant $(p<0.005)$ condition $\times \mathrm{T}_{4}$ treatment interactions for LPL and lipid staining. $N D$, not determined. 

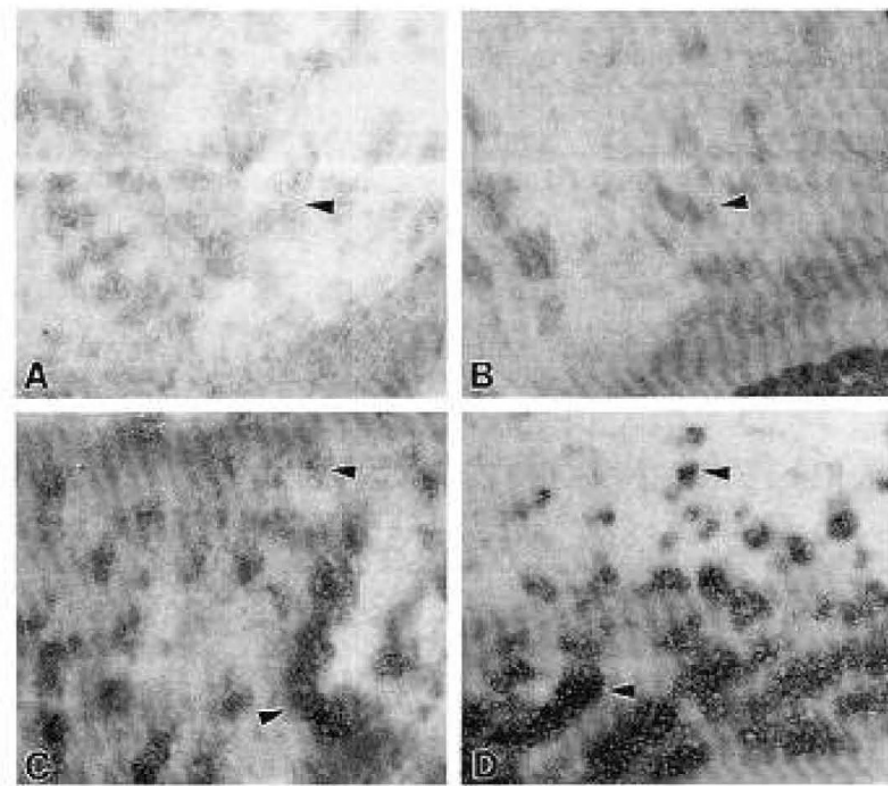

Fig. 5. Esterase cytochemistry in adipose tissue sections from $A$, a control (intact) fetus; $B$, a control fetus with a $15-\mathrm{mg} \mathrm{T} \mathrm{T}_{4}$ pellet, $C$, a hypox fetus; and $D$, a hypox fetus with a $15-\mathrm{mg} \mathrm{T}_{4}$ pellet. Fat cell clusters (arrowheads) in sections from treated and untreated controls are devoid of esterase reactivity $(A, B)$, in contrast to positive reactions in fat cell clusters from hypox fetuses $(C)$. Treatment with $\mathrm{T}_{4}$ greatly augmented this hypox-induced appearance of esterase reactivity in fat cell clusters ( $C$ vs $D$ ). Note that fat cell clusters in the outer aspects of the sections are intensely enzyme reactive in $D$ (arrowheads), but are not reactive in $C$ (arrowheads). The appearance of cytochemically detectable enzyme activity follows a ventral to dorsal gradient (lower to outer). Cryostat sections $(24 \mu \mathrm{m})$ reacted for esterase activity. Original magnification, $\times 20$.

\section{DISCUSSION}

The results presented herein clearly show that experimentally elevated levels of serum $\mathrm{T}_{4}$ were associated with distinct morphologic changes in skin and subcutaneous tissue of hypox and intact porcine fetuses. For instance, skin and hair development was markedly stimulated and the myxedema of the subcutaneous tissue (thickness) was reversed by $\mathrm{T}_{4}$ treatment. These effects are typical for $T_{4}(22)$, whereas the unexpected and remarkable aspect of the present study was that $\mathrm{T}_{4}$ did not, by any measure, influence adipose tissue development in intact fetuses, but profoundly enhanced adipose tissue development in hypox fetuses. One explanation of this apparent discrepancy is that a pituitaryderived or pituitary-dependent hormone effectively antagonized the adipogenic potential of $\mathrm{T}_{4}$ in intact fetuses. Consideration of relevant in vivo $(3-5)$ and in vitro $(6,8)$ results suggests that $\mathrm{GH}$ may be the antagonistic hormone. For instance, low GH levels and elevated $\mathrm{T}_{4}$ levels were associated with enhanced adipose tissue development in two fetal models $(3,5)$. Furthermore, numerous studies of growing swine show that daily injections of GH markedly reduce carcass fat deposition and enhance lean deposition (for review see Ref. 23). Porcine and rat preadipocyte development in vitro is also antagonized by $\mathrm{GH}$ and enhanced by $\mathrm{T}_{4}(6-8)$, and hypox per se enhances the adipogenic potential of fetal pig serum on preadipocyte cultures (6). Therefore, the data in the present study coupled with supporting evidence indicate that GH may antagonize the adipogenic potential of $\mathrm{T}_{4}$ in the fetal pig. However, there is a preponderance of evidence from studies of preadipocyte cell lines indicating that $\mathrm{GH}$ enhances adipogenesis at the cellular and molecular level (for review see Ref. 24). More definitive studies of $\mathrm{GH}$ in vivo are needed to resolve the issue of $\mathrm{GH}$ and adipogenesis.

The dicotomy of the fetal adipose tissue response to $T_{4}$ treatment could also be explained by consideration of potential involvement of lipogenic substrates and hormones. For instance, hypox per se could elevate insulin levels as observed in a previous study (25) and $\mathrm{T}_{4}$ treatment of hypox fetuses could elevate insulin levels further, as well as enhance cortisol secretion at the level of the adrenal gland (26). However, insulin levels were not affected by hypox (with and without $\mathrm{T}_{4}$ treatment) and cortisol levels were not affected by $\mathrm{T}_{4}$ treatment in the present study. However, insulin levels in the current study may be artifactually low because fetuses need to be chronically catheterized to properly evaluate fetal pig insulin levels (27). Therefore, the serum insulin status in the present study is not clear and the possible association of serum insulin and $T_{4}$ with adipose tissue development in the fetus is in need of more study. IGF-I levels were significantly
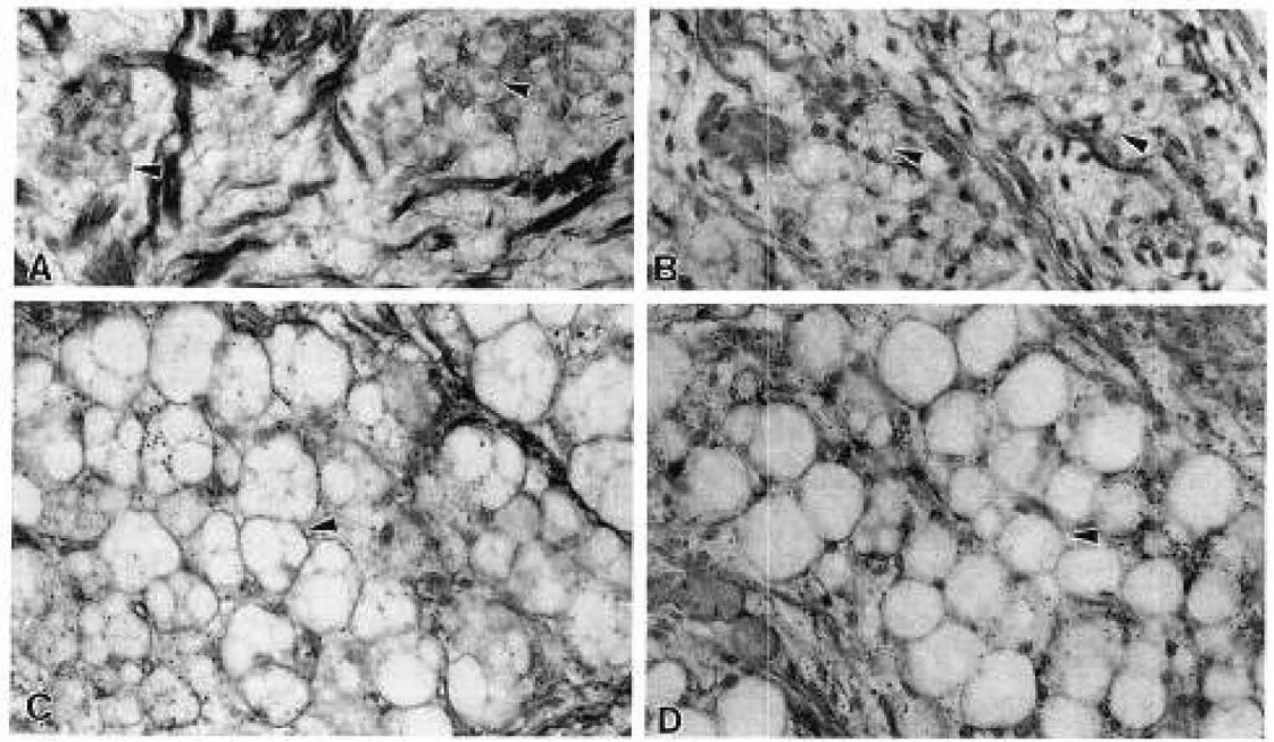

Fig. 6. The morphology of fat cells (arrowheads) in sections of wax-embedded tissues from $A$, a control (intact) fetus; $B$, a control fetus with a $15-\mathrm{mg} \mathrm{T}_{4}$ pellet; $C$, a hypox fetus; and $D$, a hypox fetus with a $15-\mathrm{mg} \mathrm{T}_{4}$ pellet. Fat cell morphology was not influenced by $\mathrm{T}_{4}$ treatment of control fetuses $(A v S B)$. However, hypox increased fat cell size $(A v S C)$ and $\mathrm{T}_{4}$ treatment of hypox fetuses induced a unilocular morphology $(D)$ in most

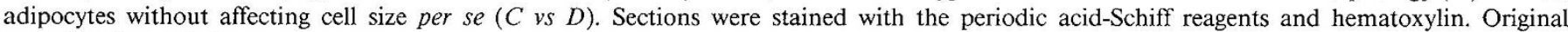
magnification, $\times 350$. 
elevated in hypox fetuses treated with $\mathrm{T}_{4}(28)$. However, IGF-I is ineffective in cultures of fetal pig cells (29), despite having a positive affect on preadipocyte development in cultures of cells from young pigs $(7,30)$. Therefore, elevated IGF-I levels may not account for the augmented adipose cell development in $T_{4^{-}}$ treated hypox fetuses. And finally, serum glucose and triglyceride levels were not elevated in $\mathrm{T}_{4}$-treated hypox fetuses (Hausman $\mathrm{DB}$, unpublished observations), which suggests that these metabolites were also not associated with adipose cell development in $\mathrm{T}_{4}$-treated hypox fetuses.

This study is the first to demonstrate an effect of $\mathrm{T}_{4}$ on the cellular development of fetal adipose tissue. Specifically, $\mathrm{T}_{4}$ slightly increased fat cell size, but markedly enhanced fat cell cluster hypertrophy and lipogenic enzyme activity in hypox fetuses. Fat cell size was independent of $\mathrm{T}_{4}$ dose (hypox fetuses), but only the largest $T_{4}$ dose $(15 \mathrm{mg})$ induced a significant increase in fat cell cluster growth (percentage of area, lipid-stained sections). This fat cell cluster growth cannot be accounted for by an increase in fat cell size and therefore had to be associated with an apparent increase in fat cell number. Although this is indirect evidence, it does demonstrate, for the first time, that preadipocyte recruitment and/or replication as well as differentiation was enhanced by $T_{4}$ in the fetus. These results are consistent with results of in vitro studies in which $\mathrm{T}_{4}$ supplementation of serum from hypox fetuses enhanced the capacity of serum to stimulate preadipocyte replication and differentiation (6). Therefore, in vitro and in vivo data suggest that $\mathrm{T}_{4}$ plays a primary role in fetal preadipocyte recruitment and/or replication and differentiation.

Consideration of the various adipose tissue responses in hypox fetuses indicates that only LPL activity responded to $T_{4}$ treatment in a dose-dependent manner. For instance, the extent of LPL staining (percentage of area) in hypox fetuses was greatest with $15 \mathrm{mg} \mathrm{T}_{4}$, lowest with no $\mathrm{T}_{4}$, and intermediate with $5 \mathrm{mg} \mathrm{T}$ treatments. Furthermore, the intensity of LPL staining (AGV) was enhanced by the low $\mathrm{T}_{4}$ dose $(5 \mathrm{mg})$, which slightly increased fat cell size but did not affect fat cell cluster growth (percentage of area, lipid staining). In a relevant study, a large increase in LPL activity in adipose tissue from preobese fetuses was also associated with minimal changes in adipose tissue cellularity (3). LPL hydrolyzes blood-borne triglycerides and lipids into fatty acids for assimilation into tissue lipids (31). Therefore, blood levels of LPL substrates (lipids, etc.) are an important consideration, because LPL activity may simply reflect substrate levels (31). In fact, blood triglyceride levels were positively associated with adipose tissue LPL levels in preobese fetuses $(3,32)$, whereas LPL levels were not associated with substrate levels in the present study (no treatment effect on lipid levels). Furthermore, levels of lipogenic hormones, i.e. insulin and cortisol, were not elevated by $\mathrm{T}_{4}$ treatment and, therefore, not associated with elevated LPL levels in the present study. Therefore, $\mathrm{T}_{4}$ may directly induce LPL activity during adipocyte differentiation in hypox fetuses. However, the involvement of IGF-I as an endocrine or autocrine/ paracrine modulator of LPL cannot be eliminated. Nevertheless, the $\mathrm{T}_{4}$-treated hypox fetus is a suitable model to examine induction of LPL during adipocyte differentiation.

Fat cell clusters were reduced in number in the outer layer of adipose tissue of hypox (d 70) fetuses when examined at $110 \mathrm{~d}$ of gestation (4). In the present study, however, hypox did not reduce fat cell cluster number (outer layer), but fetuses were examined $20 \mathrm{~d}$ after hypox as opposed to $40 \mathrm{~d}$ in the previous study (4). Therefore, the effect of hypox on fat cell number is dependent upon the length of exposure to hypox. Nevertheless, the $15-\mathrm{mg} \mathrm{T}_{4}$ treatment induced greater fat cell cluster numbers in the outer layer of hypox fetuses (present study). This elevated cluster number $\left(15 \mathrm{mg} \mathrm{T}_{4}\right.$ ) could be an artifact of the counting procedure associated with the reduced subcutaneous thickness. However, the tissue thickness was reduced similarly in 5-mg and 15-mg $\mathrm{T}_{4}$-treated hypox fetuses, but cell cluster numbers were not increased by the $5-\mathrm{mg} \mathrm{T}_{4}$ treatment. Therefore, the high $\mathrm{T}_{4}$ dose increased fat cell numbers in the inner and outer layers of tissue in hypox fetuses. Additionally, there was a trend $(p<0.09)$ for higher cell cluster numbers in $15-\mathrm{mg}_{4}$-treated compared with untreated intact fetuses. Thus, $\mathrm{T}_{4}$ may dictate, in part, the hyperplastic growth of fetal adipose tissue. Definitive studies of the mechanism of action of $\mathrm{T}_{4}$ are needed to fully establish the physiologic significance of these findings.

Acknowledgments. The author thanks R. Watson, A. Latimer, and D. Slavin for the able technical execution of these studies.

\section{REFERENCES}

1. Hausman GJ, Martin RJ, Campion DR 1986 Regulation of adipose tissue development in the fetus: the fetal pig model. In: Tumbleson ME (ed) Swine in Biomedical Research. Plenum Press, New York, pp 997-1006

2. Hausman GJ, Wright JT, Jewell DE, Ramsay TG 1990 Fetal adipose tissue development. Int J Obesity 14:177-185

3. Hausman GJ, Campion DR, Thomas GB 1983 Adipose tissue cellularity and histochemistry in fetal swine as affected by genetic selection for high or low backfat. J Lipid Res 24:223-228

4. Hausman GJ, Hentges EJ, Thomas GB 1987 The differentiation of adipose tissue and muscle in hypophysectomized pig fetuses. J Anim Sci 64:12551261

5. Hausman GJ, Kasser TR, Martin RJ 1982 The effect of maternal diabetes and fasting on fetal adipose tissue histochemistry in the pig. J Anim Sci 56:838845

6. Ramsay TG, Hausman GJ, Martin RJ 1987 Preadipocyte proliferation and differentiation in response to hormone supplementation of decapitated fetal pig sera. J Anim Sci 63:735-744

7. Hausman GJ 1989 The influence of insulin, triiodothyronin (T3) and insulinlike growth factor-1 (IGF-1) on differentiation in serum free cultures of pig stromal-vascular cells. J Anim Sci 67:3136-3143

8. Hausman GJ, Martin RJ 1989 The influence of human growth hormone on preadipocyte development in serum supplemented and serum free cultures of stromal-vascular cells from pig adipose tissue. Domest Anim Endocrinol 6:331-337

9. Fentener van Vlissinger JM, Colenbrander B, Wensing CJ 1983 Morphological development of the thyroid gland and serum $\mathrm{T} 4$ concentrations in the intact and decapitated pig fetus. J Dev Physiol 5:361-371

10. McNamara M, Vandalem JL, Hennen G, Colenbrander B, Macdonald AA, van der Wiel D, Meyer J 1986 Ontogeny of hypothalamic pituitary function in the pig: pituitary thyrotropin in the fetus and neonate. $J$ Endocrinol 111:111-115

11. Walsh-Hentges LS, Martin RJ 1988 Influence of genetic obesity on maternal and fetal serum and lipoprotein lipids in swine. Int J Obesity 12:49-56

12. Randall GCB 1986 Chronic implantation of catheters and other surgical techniques in fetal pigs. In: Tumbleson ME (ed) Swine in Biomedical Research. Plenum Press, New York, pp 1179-1186

13. Hausman GJ, Kauffman RG 1986 The histology of developing porcine adipose tissue. J Anim Sci 63:642-659

14. Hausman GJ 1981 Techniques for studying adipocytes. Stain Tech 56:149154

15. Rieder H, Teutsh HF, Sasse D 1978 NADP-dependent dehydrogenases in rat liver parenchyma. Histochemistry 56:283-298

16. Hausman GJ, Wright JT, Thomas GB 1991 Vascular and cellular development in fetal adipose tissue: lectin binding studies and immunocytochemistry for laminin and type IV collagen. Microvasc Res 6:331-337

16a. Heimer GV, Taylor CED 1974 Improved mountant for immunofluorescence preparations. J Clin Pathol 27:254

17. Sjostrom L, Bjorntorp P, Vrana J 1971 Microscopic fat cell size measurements on frozen-cut adipose tissue in comparison with automatic determinations of osmium-fixed fat cells. J Lipid Res 12:521-535

18. Humason GL 1972 Animal Tissue Techniques. Freeman, San Francisco

19. Kraeling RR, Rampacek GB, Cox NM, Kiser TE 1982 Prolactin and luteinizing hormone secretion after bromocryptine (CB-154) treatment in lactating sows and ovariectomized gills. J Anim Sci 54:1212-1220

20. 1985 SAS User's Guide. SAS Institute, Inc., Cary, NC

21. Randall GCB 1989 Effect of hypophysectomy on body and organ weights and subsequent development in the fetal pig. Can J Anim Sci 69:655-661

22. Gorbman A, Dickoff WW, Vigna SR, Clark NB, Ralph CL 1983 Comparative Endocrinology. John Wiley \& Sons, New York, pp 185-274

23. Boyd RD, Bauman DE 1989 Mechanisms of action for somatotropin in growth In: Campion DR, Hausman GJ, Martin RJ (eds) Animal Growth Regulation. Plenum Press, New York, pp 257-284

24. Hausman GJ, Jewell DE, Hentges EJ 1989 Endocrine regulation of adipogenesis. In: Campion DR, Hausman GJ, Martin RJ (eds) Animal Growth Regulation. Plenum Press, New York, pp 49-64 
25. Martin RJ, Campion DR, Hausman GJ, Gahagan JH 1984 Serum hormones and metabolites in fetally decapitated pigs. Growth 48:158-165

26. Turner CD, Bagnara JT 1971 General Endocrinology. WB Saunders, Philadelphia, pp 182-201

27. Fowden AL, Bloom SR 1986 The endocrine pancreas of the fetal pig. In: Tumbleson ME (ed) Swine in Biomedical Research. Plenum Press, New York, pp 1195-1204

28. Hausman GJ, Latimer AM, Hausman DB 1991 Thyroxine and fetal development: growth, insulin-like growth factor-1 and adipose tissue development. FASEB J 5:A955 (abstr)
29. Hausman GJ 1992 Responsiveness to adipogenic agents in stromal-vascular cultures derived from lean and pre-obese fetuses: an ontogeny study. J Anim Sci 70:106-114

30. Ramsay TG, White ME, Wolverton CK 1989 Insulin-like growth factor 1 induction of differentiation of porcine preadipocytes. J Anim Sci 67:24522459

31. Vernon R, Clegg RA 1985 The metabolism of white adipose tissue in vivo and in vitro. In: Cryer A, Van RLR (eds) New Perspectives on Adipose Tissue: Structure, Function and Development. Butterworths, London, pp 65-8

32. Martin RJ, Ramsay TG, Campion DR, Hausman GJ 1985 Fetal hormone and metabolite levels in lean and obese pigs. Growth 49:400-407 